See discussions, stats, and author profiles for this publication at: https://www.researchgate.net/publication/293192171

\title{
Potential of Entomopathogenic Fungi as Biological Control Agents of Diamondback Moth (Lepidoptera: Plutellidae) and Compatibility With Chemical Insecticides
}

Article in Journal of Economic Entomology · February 2016

DOI: 10.1093/jee/tow008

\section{CITATIONS}

18

7 authors, including:

R.T. Duarte

Centro Universitário de Araraquara

105 PUBLICATIONS 55 CITATIONS

SEE PROFILE

Sergio A De Bortoli

São Paulo State University

1,110 PUBLICATIONS 1,256 CITATIONS

SEE PROFILE
READS

387

David Jossue López Espinosa

Universidade Federal de Alagoas

5 PUBLICATIONS 18 CITATIONS

SEE PROFILE

Ricardo Polanczyk

São Paulo State University

167 PUBLICATIONS 441 CITATIONS

SEE PROFILE

Some of the authors of this publication are also working on these related projects:

Metodologia de criação de insetos em laboratório View project

Tactics for the integrated pest management of Plutella xylostella (L. , 1758) ( Lep .: Plutellidae ) in Brassicaceae. View project 


\title{
Potential of Entomopathogenic Fungi as Biological Control Agents of Diamondback Moth (Lepidoptera: Plutellidae) and Compatibility With Chemical Insecticides
}

\author{
R. T. Duarte, ${ }^{1,2}$ K. C. Gonçalves, ${ }^{1}$ D.J.L. Espinosa, ${ }^{1}$ L. F. Moreira, ${ }^{1}$ S. A. De Bortoli, ${ }^{1}$ \\ R. A. Humber, ${ }^{3}$ and R. A. Polanczyk ${ }^{1}$ \\ 1Department of Plant Protection, Faculty of Agronomy and Veterinary Sciences, Sao Paulo State University "Júlio de Mesquita \\ Filho" (Unesp), Jaboticabal, SP 14884-900, Brazil (rogerio.tduarte@yahoo.com.br; kellcrist2010@hotmail.com; daespi24.7@gmail. \\ com; laka_moreira@hotmail.com; bortoli@fcav.unesp.br; rapolanc@yahoo.com.br), ${ }^{2}$ Corresponding author, e-mail: rogerio. \\ tduarte@yahoo.com.br, and ${ }^{3}$ Emerging Pests and Pathogens Research, United States Department of Agriculture - Agricultural \\ Research Service, Robert W. Holly Center for Agriculture and Health, Ithaca, NY 14853-2901 (richard.humber@ars.usda.gov)
}

Received 23 October 2015; Accepted 13 January 2016

\begin{abstract}
The objectives were to evaluate the efficiency of entomopathogenic fungi against Plutella xylostella (L.) and the compatibility of the most virulent isolates with some of the insecticides registered for use on cabbage crops. Pathogenicity tests used isolates of Beauveria bassiana, Metarhizium rileyi, Isaria fumosorosea, Isaria sinclairii, and Lecanicillium muscarium standardized at a concentration of $10^{7}$ conidia $/ \mathrm{ml}$. Cabbage leaf discs were immersed in these suspensions, and after evaporation of the excess water, were placed 10 second-instar larvae of $P$. xylostella, totaling 10 leaf discs per treatment. Mortality was assessed $7 \mathrm{~d}$ after treatment, and the isolates that caused mortality $>80 \%$ were used to estimate $L C_{50}$ and $L T_{50}$. The compatibilities of the most virulent isolates and the insecticides were tested from the mixture of these into the culture medium, and after solidifying, the medium was inoculated with an aliquot of the isolated suspension. The following parameters were evaluated: growth of the colony, number and viability of conidia after $7 \mathrm{~d}$. The isolated IBCB01, IBCB18, IBCB66, and IBCB87 of $B$. bassiana, LCMAP101 of $M$. rileyi, and ARSEF7973 of $I$. sinclairii caused mortality between 80 and $100 \%$, with $\mathrm{LC}_{50}$ and $\mathrm{LT}_{50}$ between 2.504 to $6.775 \times 10^{4}$ conidia/ml and 52.22 to $112.13 \mathrm{~h}$, respectively. The active ingredients thiamethoxam and azadirachtin were compatible with the entomopathogenic fungi. The results suggest that the use of these isolates is an important alternative in the pesticidal management of $P$. $x y l o s t e l l a$, with the possible exception of the associated use of chemical controls using the active ingredients thiamethoxam or azadirachtin.
\end{abstract}

Key words: Plutella xylostella, biological control, chemical control, interaction

The diamondback moth, Plutella xylostella (L.) (Lepidoptera: Plutellidae), is a major pest of plants in the family Brassicaceae in many parts of the world. The impacts of this pest are magnified by its great capacity to disperse, by its adaptability to adverse weather conditions, and is intensified by its short life cycle and high reproductive rates (Honda et al. 1992, Chapman et al. 2002, Coulson et al. 2002, Ulmer et al. 2002, Attique et al. 2006, Sarfraz et al. 2006, Grzywacz et al. 2010). In Brazil, this species is important in most areas of brassica cultivation (Marchioro and Foerster 2014), and it distributed from the Amazon to the state of Rio Grande do Sul (Ferronatto 1984, Castelo Branco and Guimarães 1990, Barros et al. 1993, Melo et al. 1994, Cardoso 1999, Cardoso et al. 2012).

Among commercial species, cabbage (Brassica oleracea var. capitata) is one of the main hosts of this microlepidopteran. Diamondback moth larvae feed on leaf tissue, and cause quantitative and qualitative damage ranging from yield losses to the death of the plant, and may infest as much as $100 \%$ of the plants in individual fields (Ooi and Kelderman 1979, Shelton et al. 1982, Barros et al. 1993, Castelo Branco et al. 1997, Ohsawa 2001, Monnerat et al. 2004). To reduce the population densities of this pest, chemical control methods using highly toxic, broad-spectrum insecticides have been the main pest control strategy, with particular dependence on pyrethroid and organophosphate active ingredients (Castelo Branco and Medeiros 2001, Castelo Branco et al. 2003, Filgueira 2007). However, the high selection pressure induced by excessive applications is one of crucial factors for increasing incidence of resistance of populations of P. xylostella to many classes of chemical insecticides (Castelo Branco et al. 2003, Sarfraz and Keddie 2005, Sayyed et al. 2005, Zhao et al. 2006, Thuler et al. 2007, Endersby et al. 2008, Oliveira et al. 2011). 
To minimize this problem, different biological control agents can contribute to the control of P. xylostella, especially using entomopathogenic microorganisms, such as fungi complex, composed by Beauveria bassiana (Bals.-Criv.) Vuill., Metarhizium anisopliae (Metsch.) Sorok., Metarhizium rileyi (Farlow) Kepler, S.A. Rehner \& Humber, Isaria sp., and Lecanicillium sp. (Gopalakrishnan 1989, Silva et al. 2003, Godonou et al. 2009, Xu et al. 2011, Méndez 2012). One of the barriers to using more efficient and also the conservation of these microbial agents in the field is related to the compatibility with the pesticides used to control other pests or agricultural diseases (Batista Filho et al. 2001, Almeida et al. 2003, Batista Filho et al. 2003, Cuthbertson et al. 2005, Wenzel et al. 2008, Botelho and Monteiro 2011, Niassy et al. 2012, Schumacher and Poehling 2012).

However, few studies relate the potential of different species of entomopathogenic fungi in the biological control of P. xylostella and the possible compatibility of these with the chemical insecticides (Tian and Feng 2006), which requires better understanding of possible interactions between these microbiological and chemical agents involved with the aim of improve control strategies. The objectives of this research were to analyze the efficiency of entomopathogenic fungi to control second-instar larvae of P. xylostella and to evaluate the compatibility of the most virulent isolates with the active ingredients of insecticides registered for the control of cabbage crop pests.

\section{Materials and Methods}

\section{P. xylostella Population}

Bioassays were conducted using a population of P. xylostella originating from a conventionally farmed commercial cabbage field in the municipality of Recife (Pernambuco), from a collection of 143 adults on 15 January 2007. This population was maintained at the Laboratory of Biology and Insects Rearing (LBIR) and kept reproductively isolated using a rearing methodology described by De Bortoli et al. (2011).

For laboratory rearings, the larval stage of $P$. xylostella were fed leaves (45-60 d old) of cabbage (B. oleracea var. capitata cv. Chato de Quintal); this cultivar is known to be susceptible to diamondback moth (Boiça Júnior et al. 2013). Plants $\sim 20$ d old were obtained from the company Agrimonte Produtos Agrícolas Ltda. (Monte Alto São Paulo, Brazil), and transplanted individually in polyethylene pots with a capacity of 5 liters, containing a homogeneous mixture of soil (red latosol), coarse sand, and cattle manure sifted together in a proportion of 2:1:1 (Boiça Júnior et al. 2013). These pots were placed in the greenhouse. Cabbage seedlings were transplanted on a monthly basis to maintain constant leaf production to feed the diamondback moth larvae.

The rearing of adults was conducted in transparent plastic cylindrical containers $(15 \mathrm{~cm}$ diameter by $25 \mathrm{~cm}$ height), containing a cabbage leaf disc $8 \mathrm{~cm}$ in diameter in a filter paper disc of the same diameter that was slightly moistened with distilled water. This paper disc was placed in a transparent plastic cup $(5 \mathrm{~cm}$ diameter by $8 \mathrm{~cm}$ height) with the opening turned down, containing the elevated cabbage leaf disc inside the cage, where oviposition occurred. The top of the container included a 3 -cm-diameter opening over which was placed a sponge soaked with a $10 \%$ aqueous solution of honey. In each cage also included a lateral opening $(10 \mathrm{~cm}$ length by $10 \mathrm{~cm}$ width), covered with tissue type "voile," to allow gas exchange. These leaf discs were replaced daily; discs with the presence of the diamondback moth eggs were transferred to Petri dishes $(9 \mathrm{~cm}$ diameter) until the outbreak of larvae.

\section{Entomopathogenic Fungal Isolates}

The fungal isolates used in bioassays belong to species $B$. bassiana, Lecanicillium muscarium (Petch.) Zare \& W. Gams, Isaria fumosorosea Wize, Isaria sinclairii (Berk.) Lloyd, and M. rileyi (Table 1). These isolates were grown on potato dextrose agar (PDA) and stored in test tubes or Petri dishes ( $9 \mathrm{~cm}$ diameter) at a temperature of $-4^{\circ} \mathrm{C}$ (freezer) at the Laboratory of Microbial Control of Pests (LMCP) bank. For their use, the isolates were transferred to Petri dishes ( $9 \mathrm{~cm}$ diameter) containing PDA, and incubated at a temperature of $28 \pm 2^{\circ} \mathrm{C}, 70 \pm 10 \%$ relative humidity $(\mathrm{RH})$, and a photoperiod of 12:12 (L:D) h for $15 \mathrm{~d}$. Thereafter, conidial suspensions were prepared in $10 \mathrm{ml}$ autoclaved water $+0.05 \%$ Tween 20 (as an adhesive spreader) + fungal conidia. From this suspension, two serial dilutions were made to quantify the number of conidia/ml, with the help of a Neubauer chamber, and standardized at a final concentration of $10^{7}$ conidia/ml.

\section{Pathogenicity of Entomopathogenic Fungal Isolates}

Ten second-instar larvae of P. xylostella were placed on each of 10 leaf cabbage leaf discs $(8 \mathrm{~cm}$ diameter) for each treatment (with a total of 10 replicates per experiment). The B. oleracea var. capitata cv. Chato de Quintal leaf discs for these bioassays were immersed in $10 \mathrm{ml}$ of the conidial suspensions of each fungus for $1 \mathrm{~min}$, and then dried before adding the diamondback moth larvae.

After this procedure, leaf disks were transferred individually to Petri dishes containing distilled water-moistened filter paper $(8 \mathrm{~cm}$ diameter). A soft brush was used to transfer 10 second-instar larvae of P. xylostella to each leaf disc, and the dishes were placed in a growth chamber at $25 \pm 2{ }^{\circ} \mathrm{C}, 70 \pm 10 \% \mathrm{RH}$, and a photoperiod of 12:12 (L:D) h. The control treatments followed the same methodology described earlier without adding any fungus to the autoclaved Tween solutions.

Mortality was assessed on the 7th day after treatment application, when dead insects were placed in a humid chamber to confirm whether the larvae were killed by the entomopathogen. The humid chamber consisted of filter paper disc $(8 \mathrm{~cm}$ diameter $)$ and a foam, both sterilized and moistened with distilled water, placed on Petri dishes $(9 \mathrm{~cm}$ diameter) and maintained in growth chamber at $28 \pm 2{ }^{\circ} \mathrm{C}, 70 \pm 10 \% \mathrm{RH}$, and a photoperiod of $12: 12$ (L:D) h. Confirmation of mortality was performed after $10 \mathrm{~d}$ of incubation in the humid chamber by observing the conidial structures of the fungus with a stereoscopic microscope model Stemi 2000-C, Carl Zeiss Corporation, Germany.

Total mortality was corrected in relation to the mortality observed in control (Abbott 1925). The experiment was conducted in a completely randomized design, and the data were submitted to analysis of variance. Means were compared by the Tukey's test $(P<0.05$; PROC GLM, SAS Institute 2002). The median lethal concentration $\left(\mathrm{LC}_{50}\right)$ and median lethal time $\left(\mathrm{LT}_{50}\right)$ were determined for isolates that caused $>80 \%$ mortality, using probit analysis $(P>0.05)$ by Minitab 15 (Minitab 2007) statistical software.

\section{Estimate of $\mathrm{LC}_{50}$ and $\mathrm{LT}_{50}$}

The estimate of $\mathrm{LC}_{50}$ was performed for conidial suspensions of $10^{4}, 10^{5}, 10^{6}, 10^{7}$, and $10^{8}$ conidia/ml, using the mortality recorded on the 7 th day after treatment application. The estimate of $\mathrm{LT}_{50}$ were prepared from 10 replicates for each isolate used and treated as indicated earlier. The fungus-induced mortality of larvae was 
Table 1. Isolates of the entomopathogenic fungi used in bioassays

\begin{tabular}{lll}
\hline Entomopathogen & Isolates & Origin \\
\hline B. bassiana & IBCB01 & Biological Control Laboratory of Experimental Center of the Biological Institute, Campinas (SP) \\
IBCB17 & \\
IBCB18 & \\
IBCB33 & \\
IBCB35 & \\
IBCB63 & \\
IBCB66 & Microbiology Laboratory of the Department of Plant Protection (Unesp), Jaboticabal (SP) \\
IBCB87 & \\
JAB01 & \\
JAB09 & \\
JAB48 & United States Department of Agriculture (USDA)-Collection of Entomopathogenic Fungal \\
J. muscarium & JAB63 & Cultures, Ithaca (USA) \\
I. fumosorosea & ARSEF5128 & \\
ARSEF7050 & ARSEF6925 & \\
ARSEFi & LCMAP101 & Laboratory of Microbial Control of Pests (Unesp), Jaboticabal (SP)
\end{tabular}

checked every $24 \mathrm{~h}$ for $7 \mathrm{~d}$. The conduct of bioassays related to $\mathrm{LC}_{50}$ and $\mathrm{LT}_{50}$ was identical to the methodology described earlier to assess pathogenicity.

Confirmation of the causes of mortality was performed $10 \mathrm{~d}$ after the transfer of dead larvae into the humid chamber by monitoring for the presence of conidial structures as described earlier. The mortality results were subjected to probit analysis $(P>0.05)$ using Minitab 15 (Minitab 2007) statistical software.

\section{Compatibility Between Entomopathogenic Fungi and Pesticides}

The most virulent isolates of fungal pathogens against $P$. xylostella were used in compatibility tests with active ingredients of pesticides routinely used on cabbage crops: azadirachtin (AzaMax; $200 \mathrm{ml} \times$ 100 liter $^{-1}$ ), deltamethrin (Decis; $30 \mathrm{ml} \times 100$ liter $^{-1}$ ), methomyl (Lannate BR; $100 \mathrm{ml} \times 100$ liter $^{-1}$ ), thiamethoxam (Actara; $20 \mathrm{~g} \times 100$ liter $^{-1}$ ), and acephate (Orthene; $100 \mathrm{~g} \times 100$ liter $^{-1}$; Mapa 2013).

The toxic effect of insecticides on the entomopathogenic fungi was determined by adding the chemical products to PDA culture medium, prepared from the dissolution of $39 \mathrm{~g}$ of the formulated medium, Potato Dextrose Agar (HiMedia Laboratories Pvt. Ltd., Mumbai, India), in 1 liter of distilled water, and subsequently autoclaved at $1 \mathrm{~atm}$ for $20 \mathrm{~min}$. After autoclaving, when the medium had cooled to $45^{\circ} \mathrm{C}$ but not yet solidified yet was cool enough not to affect the activities of the pesticides (Botelho and Monteiro 2011), each pesticide was added and homogenized into the culture medium, and then poured onto Petri dishes to solidify. For each test, pesticides were prepared and inoculated in 10 Petri dishes from a single batch of fungal inoculum and the experiment was replicated 10 times (ten replicates).

These pesticide-supplemented plates were inoculated with $5 \mu \mathrm{l}$ each of conidial suspensions $\left(10^{7}\right.$ conidia/ml $)$ for each fungal isolate. Plates were then incubated at $28 \pm 2{ }^{\circ} \mathrm{C}, 70 \pm 10 \% \mathrm{RH}$, and a photoperiod of 12:12 (L:D) h for $7 \mathrm{~d}$. Thereafter, the total area $\left(\mathrm{cm}^{2}\right)$ of colonies was measured by cutting blank sheet of paper the same size as the colonies and measuring the areas of this piece of paper using a leaf area meter unit (Model CI-202, CID Bio-Science, WA).

After colony growth was measured, conidial production of each plate was determined by cutting up the colony culture medium, and placing the colony pieces in the tubes with $10 \mathrm{ml}$ of sterile $0.05 \%$ Tween-20 solution and agitated vigorously with a Model AP56 agitator (Phoenix, São Paulo, Brazil) for a period of $1 \mathrm{~min}$. Then, a small aliquot of the resultant conidial suspension was counted with a Neubauer hemacytometer to estimate conidial production on each plate.

The viability of conidia was analyzed by microculture technique and direct examination using blade, proposed by Marques et al. (2004). For each test, treatments were prepared and inoculated in 10 microscopy blade from a single batch of fungal inoculum and the experiment was replicated five times (five replicates). The experiment was conducted in a completely randomized design, and the data were submitted to analysis of variance and the average size of the colonies, the number, and viability of conidia for each treatment were compared by Tukey's test at 5\% probability (PROC GLM, SAS Institute 2002).

The biological index was standardized by compatibility score developed by Alves et al. (2007), with the help of the following formula $\quad(\mathrm{BI}=47 \quad[\mathrm{VG}]+43 \quad[\mathrm{SP}]+10 \quad[\mathrm{GER}] / 100), \quad$ in which $\mathrm{BI}=$ biological index; $\mathrm{VG}=$ percentage of vegetative growth of the colony after $7 \mathrm{~d}$, compared with control; SP = percentage of colony sporulation after $7 \mathrm{~d}$, compared with control; and GER = percentage of spore germination after $24 \mathrm{~h}$. Alves et al. (2007) ranked biological index values as follows: $\mathrm{BI}>66$ as compatible, $42 \leq \mathrm{BI} \leq 66$ as moderately toxic, and $\mathrm{BI}<42$ as toxic.

\section{Results and Discussion}

All analyzed isolates were pathogenic to P. xylostella, with mortality rates ranging between 46 and $100 \%$ (Fig. 1). The fungi that caused mortality $>80 \%$ were B. bassiana, $I$. sinclairii, and M. rileyi, highlighting the isolates IBCB01, IBCB18, IBCB66 (B. bassiana), and LCMAP101 (M. rileyi), responsible for mortality between 98 and $100 \%$ of second-instar larvae of P. xylostella, not differing statistics from each other, followed by ARSEF7973 (I. sinclairii) and IBCB87 (B. bassiana), with 80 and $94 \%$ mortality, respectively (Fig. 1).

The estimated $\mathrm{LC}_{50}$ varied from 2.504 and $6.775 \times 10^{4}$ conidia/ $\mathrm{ml}$, with a significant difference only between $B$. bassiana isolates IBCB01 and IBCB18, with the first of these isolates being characterized as the most virulent (Table 2). Metarhizium rileyi LCMAP101 


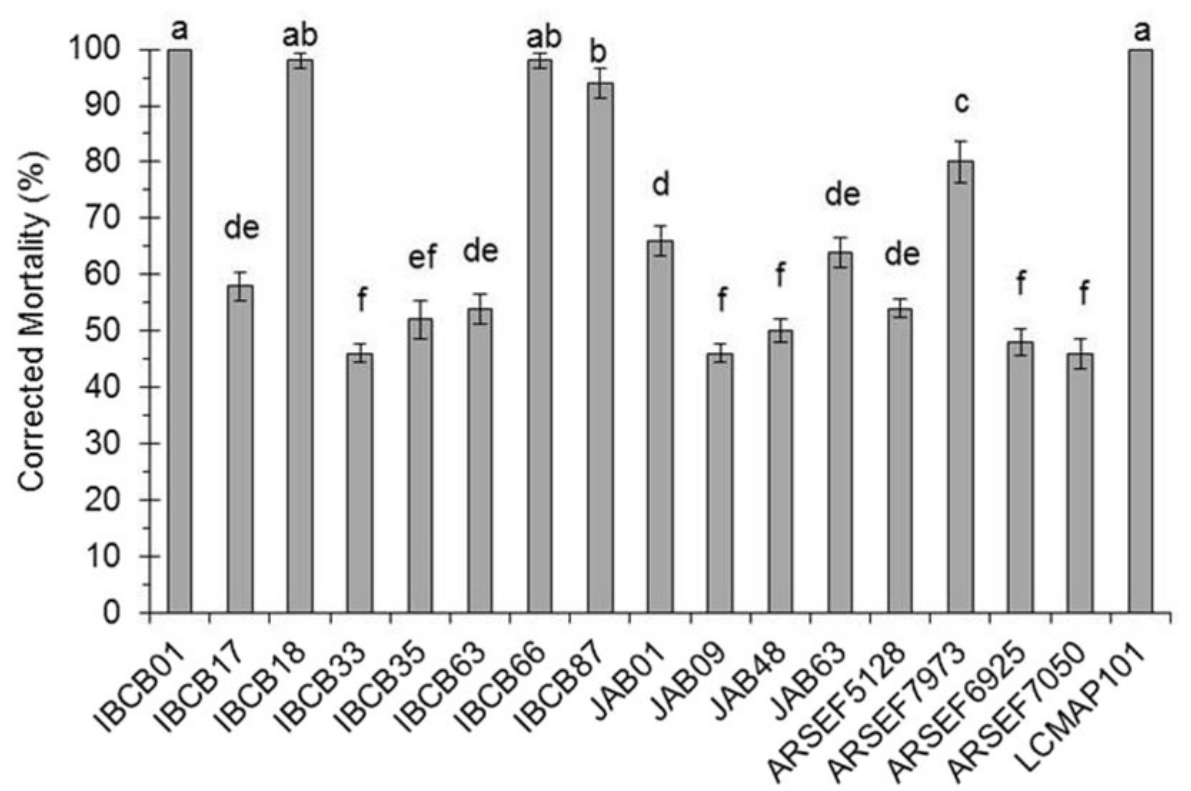

Fig. 1. Corrected mortality of second-instar larvae of $P$. xylostella subjected to treatments using entomopathogenic fungi. Means followed by the same letter do not differ significantly $(P<0.05)$. The error bar represents the standard error $( \pm \mathrm{SE})$.

Table 2. Estimated $\mathrm{LC}_{50}$ of the most virulent entomopathogenic fungi isolates to second-instar larvae of $P$. xylostella

\begin{tabular}{lcclr}
\hline Treatments & N & Slope \pm SE & $\begin{array}{c}\mathrm{LC}_{50}\left(\mathrm{CI}_{95} \%\right) \times 10^{4} \\
\text { conidia/ml }\end{array}$ & $\chi 2^{*}$ \\
\hline $\begin{array}{l}\text { B. bassiana } \\
\text { IBCB01 }\end{array}$ & 500 & $0.37 \pm 0.04$ & $2.504(1.442-3.923)$ & 5.26 \\
IBCB18 & 500 & $0.31 \pm 0.03$ & $6.775(3.975-10.756)$ & 13.31 \\
IBCB66 & 500 & $0.36 \pm 0.03$ & $2.887(1.667-4.548)$ & 7.20 \\
IBCB87 & 500 & $0.25 \pm 0.02$ & $3.796(1.249-4.822)$ & 8.79 \\
$\begin{array}{l}\text { I. sinclairii } \\
\text { ARSEF7973 }\end{array}$ & 500 & $0.27 \pm 0.03$ & $4.600(2.436-7.774)$ & 28.89 \\
$\begin{array}{l}\text { M. rileyi } \\
\text { LCMAP101 }\end{array}$ & 500 & $0.34 \pm 0.03$ & $2.506(1.377-4.057)$ & 5.07 \\
\hline
\end{tabular}

* Chi-square test $(P>0.05)$.

Table 3. Estimated $\mathrm{LT}_{50}$ (h) of the most virulent entomopathogenic fungi isolates to second-instar larvae of $P$. xylostella

\begin{tabular}{lcccc}
\hline Treatments & $N$ & Slope $\pm \mathrm{SE}$ & $\mathrm{LT}_{50}\left(\mathrm{CI}_{95} \%\right)$ & $\chi 2 *$ \\
\hline B. bassiana & & & & \\
IBCB01 & 100 & $0.03 \pm 0.001$ & $69.56(64.72-74.21)$ & 23.05 \\
IBCB18 & 100 & $0.02 \pm 0.002$ & $63.48(58.16-68.41)$ & 10.85 \\
IBCB66 & 100 & $0.02 \pm 0.001$ & $101.66(96.77-106.62)$ & 15.43 \\
IBCB87 & 100 & $0.02 \pm 0.001$ & $84.82(78.07-91.24)$ & 15.56 \\
I. sinclairii & & & & \\
ARSEF7973 & 100 & $0.02 \pm 0.001$ & $112.13(105.93-118.69)$ & 14.22 \\
M. rileyi & & & & \\
LCMAP101 & 100 & $0.07 \pm 0.01$ & $52.22(49.52-54.88)$ & 4.64 \\
\hline
\end{tabular}

* Chi-square test $(P>0.05)$.

had the lowest $\mathrm{LT}_{50}$, which were statistically significantly different from the other treatments, and represent by the average value of $52.22 \mathrm{~h}$, followed by IBCB18 and IBCB01 with 63.48 and $69.56 \mathrm{~h}$, respectively (Table 3 ).

The B. bassiana isolates IBCB01, IBCB18, IBCB66, and IBCB87 were highly virulent to second-instar larvae of P. xylostella, and showed a high potential for management of diamondback moth pest populations. Other studies have also showed promising results for B. bassiana to control diamondback moth, but at higher applied conidial concentrations: Silva et al. (2003) reported 78-90\% mortality for second-instar diamondback moth larvae treated by $B$. bassiana isolates ESALQ 447, ESALQ 760, ESALQ 900, ESALQ 634, and IPA-205 at concentrations of $10^{8}$ conidia/ml. Batta et al. (2010) and Anaisie et al. (2011) reported $80-100 \%$ mortality, respectively, for P. xylostella larvae after treatment with B. bassiana conidia at a concentration of $10^{9}$ conidia $/ \mathrm{ml}$. In this research, the concentration $10^{7}$ conidia/ml was enough to yield mortalities between 94 and $100 \%$ for second-instar larvae of P. xylostella. The results using much lower conidial concentrations are especially interesting from an economic point of view, especially in relation to the possible development and marketing of such entomopathogenic microbes.

Another result of considerable importance from this study is the complete mortality of P. xylostella larvae $7 \mathrm{~d}$ after applications of M. rileyi (a pathogen best known for its activity against noctuid lepidopteran larvae), in addition to the fact that this fungus yielded the lowest lethal times when compared with other entomopathogens. The results show a surprisingly high virulence for this fungus against diamondback moth. This microorganism is considered pathogenic to P. xylostella, but little bit virulent (Jun 2000), in contrast to the results of this study. This virulence variability can be attributed to genetic diversity of this isolates, based on insect host and geographical region, as observed by Suwannakut et al. (2005).

Lecanicillium muscarium (Hypocreales: Cordycipitaceae) is considered to be an important control agent of Bemisia tabaci Gennadius (Hemiptera: Aleyrodidae) (Cuthbertson et al. 2005, 2008). This species proved to be pathogenic to diamondback moth, but did prove to have a lower apparent virulence than the other species entomopathogenic fungi analyzed here (Fig. 1). However, this appears to be the first report about the pathogenicity of L. muscarium for P. xylostella.

In relation to Isaria species (Hypocreales: Cordycipitaceae), it was observed that only one isolate of $I$. sinclairii presented 
Table 4. Vegetative growth $\left(\mathrm{cm}^{2} ; \pm \mathrm{SE}\right)$ of the most virulent entomopathogenic fungi isolates to $P$. $x y$ lostella when in contact with insecticides registered for the control of cabbage crop pests

\begin{tabular}{|c|c|c|c|c|c|c|}
\hline \multirow[t]{2}{*}{ Treatments } & \multicolumn{4}{|c|}{ B. bassiana } & \multirow{2}{*}{$\begin{array}{l}\text { I. sinclairii } \\
\text { ARSEF7973 }\end{array}$} & \multirow{2}{*}{$\begin{array}{c}\text { M. rileyi } \\
\text { LCMAP101 }\end{array}$} \\
\hline & IBCB01 & IBCB18 & IBCB66 & IBCB87 & & \\
\hline Control & $38.65 \pm 0.52 \mathrm{a}$ & $37.32 \pm 0.50 \mathrm{a}$ & $34.57 \pm 0.63 a$ & $34.67 \pm 0.58 \mathrm{a}$ & $26.98 \pm 0.66 a$ & $29.20 \pm 0.62 \mathrm{a}$ \\
\hline Azadirachtin & $34.63 \pm 0.43 a$ & $29.24 \pm 0.82 c$ & $30.27 \pm 0.85 b$ & $24.43 \pm 1.02 b$ & $25.23 \pm 0.81 \mathrm{a}$ & $26.32 \pm 1.13 \mathrm{ab}$ \\
\hline Thiamethoxam & $35.73 \pm 0.91 \mathrm{a}$ & $33.28 \pm 0.61 b$ & $31.73 \pm 0.75 \mathrm{ab}$ & $31.56 \pm 0.82 \mathrm{a}$ & $24.90 \pm 0.95 a$ & $26.38 \pm 0.94 a b$ \\
\hline Deltamethrin & $23.04 \pm 2.45 b$ & $21.83 \pm 0.67 \mathrm{~d}$ & $21.83 \pm 1.35 c$ & $12.39 \pm 0.79 \mathrm{~cd}$ & $16.08 \pm 0.79 b$ & $23.84 \pm 0.92 b$ \\
\hline Acephate & $18.47 \pm 1.04 b$ & $16.68 \pm 0.81 \mathrm{e}$ & $18.97 \pm 1.16 \mathrm{~cd}$ & $15.69 \pm 0.84 c$ & $13.64 \pm 0.92 b c$ & $14.56 \pm 0.81 c$ \\
\hline Methomyl & $13.28 \pm 0.91 c$ & $10.95 \pm 0.66 f$ & $16.13 \pm 1.13 \mathrm{~d}$ & $9.13 \pm 0.96 \mathrm{~d}$ & $11.37 \pm 0.94 c$ & $11.20 \pm 0.69 c$ \\
\hline$F$ & 71.15 & 218.55 & 56.49 & 153.86 & 63.53 & 70.46 \\
\hline df & 5,54 & 5,54 & 5,54 & 5,54 & 5,54 & 5,54 \\
\hline$P$ & $<0.01$ & $<0.01$ & $<0.01$ & $<0.01$ & $<0.01$ & $<0.01$ \\
\hline
\end{tabular}

Means in each column followed by same letter do not differ significantly by the Tukey's test $(P<0.05)$.

promising results against second-instar larvae of diamondback moth (Fig. 1). The few studies of this entomopathogenic genus Isaria for the possible control of this lepidopteran pest demonstrated that I. fumosorosea may cause diamondback moth mortality (Maketon et al. 2008, Huang et al. 2010) but only at economically unrealistically high conidial concentrations for the isolates test to date. The research presented here, in addition to being the first scientific report in relation to pathogenicity of $I$. sinclairii on P. xylostella, also showed the high potential of I. sinclairii in the integrated management of diamondback moth, considering the use of experimental low concentration $\left(10^{7}\right.$ conidia $\left./ \mathrm{ml}\right)$.

The difference in results between surveys may be owing to a number of factors, initially characterized by isolates of the entomopathogenic fungi, whose genetic diversity and the origin of collection can determine a response to the virulence on $P$. xylostella larvae (Hajek and St. Leger 1994, Alves 1998). Another issue is related to genetic differences of diamondback moth population used in the research, which may result in different mortality responses to the same isolated from certain species of entomopathogenic fungi. Methodological differences used in conducting pathogenicity and virulence tests can also influence directly on the larvae mortality in relation to the entomopathogenic fungi analyzed.

The compatibility test between the most virulent entomopathogenic fungi with pesticides showed no significant interference with the natural growth of the isolates when in contact with thiamethoxam, save only IBCB18 of B. bassiana (Table 4). The active ingredient azadirachtin also did not interfere significantly with vegetative growth IBCB01 of $B$. bassiana, ARSEF7973 of $I$. sinclairii, and LCMAP101 of M. rileyi. However, other chemical molecules significantly reduced vegetative growth of the colony in all isolates analyzed, especially when in contact with methomyl (Table 4).

The active ingredient thiamethoxam did not affect the number of conidia produced by entomopathogenic microorganisms, while azadirachtin, deltamethrin, acephate, and methomyl were responsible for reducing the number of conidia produced by microorganisms (Table 5).

The viability conidia was higher when in contact with the chemical molecules azadirachtin and thiamethoxam, ranging between 75.20 to $88.80 \%$ and 87.40 to $90.80 \%$, respectively, did not differ statistically to the control. The other active ingredients have reduced the viability of the reproductive structures, especially when in contact with acephate and methomyl (Table 6).

Thus, azadirachtin and thiamethoxam, following the pattern of compatibility score developed by Alves et al. (2007), were consistent with the entomopathogenic fungi tested. The deltamethrin chemical molecule was only compatible to $M$. rileyi, being moderately toxic and also toxic to other entomopathogen. The active ingredient acephate was moderately toxic when in contact with most entomopathogenic fungi, while methomyl was classified as toxic to practically every microorganisms, considered the most harmful in relation to the vegetative and reproductive development of these biological control agents (Table 7).

The compatibility of azadirachtin and thiamethoxam, ranked within the tetranortriterpenoide and neonicotinoid chemical groups, respectively, with the isolates of the entomopathogenic fungus $B$. bassiana, I. sinclairii, and M. rileyi could be related to the low toxicity of these chemical molecules for microorganisms, but also by the possible capacity of entomopathogen to degrade these compounds aiming development and reproduction (Batista Filho et al. 2001, Botelho and Monteiro 2011, Hernández et al. 2012, Niassy et al. 2012, Santos et al. 2013, Silva et al. 2013). Different studies have shown the possibility of using these active ingredients with different species of entomopathogenic fungi, showing positive results on the issues focused on compatibility (Batista Filho et al. 2001, Andaló et al. 2004, Botelho and Monteiro 2011, Hernández et al. 2012, Ribeiro et al. 2012, Rocha et al. 2012, Cintra et al. 2013).

The active ingredient deltamethrin showed different results for the species of entomopathogenic fungi, and it is considered in the most researches toxic or moderately toxic to these microorganisms (Oliveira et al. 2003, Silva et al. 2006, Archana and Ramaswamy 2012, Niassy et al. 2012), fact observed in this study, in contrast with $M$. rileyi, whose chemical molecule was consistent with that biological control agent (Table 7).

Moreover, both methomyl and acephate were harmful to the development of entomopathogens, which demonstrates the high toxicity of these molecules to these microorganisms. Both active ingredients are represented as compatible for some cases, but also moderately toxic or incompatible (Khalil et al. 1985, Batista Filho et al. 2001, Gassen et al. 2008, Wenzel et al. 2008), which may characterize differences forward to the methodology used and the variation in the dosage of pesticides used.

These laboratory results help to guide the selection of candidate fungal isolates for further laboratory and field testing to find new approaches for the microbial control of P. xylostella. From this initial process, laboratory tests on the compatibility of pesticides and the most virulent fungal isolates are vital for analyzing their possible impacts on the development and reproduction of these biological control agents, and also to help choices of insecticides that could be 
Table 5. Number of produced conidia $( \pm \mathrm{SE})$ by the most virulent entomopathogenic fungi isolates to $P$. $x y l o s t e l l a$ when in contact with insecticides registered for the control of cabbage crop pests

\begin{tabular}{|c|c|c|c|c|c|c|}
\hline \multirow[t]{2}{*}{ Treatments } & \multicolumn{4}{|c|}{ B. bassiana $\left(\times 10^{8}\right.$ conidia $)$} & \multirow{2}{*}{$\begin{array}{c}\text { I. sinclairii }\left(\times 10^{8} \text { conidia }\right) \\
\text { ARSEF7973 }\end{array}$} & \multirow{2}{*}{$\begin{array}{c}\text { M. rileyi }\left(\times 10^{8} \text { conidia }\right. \\
\text { LCMAP101 }\end{array}$} \\
\hline & IBCB01 & IBCB18 & IBCB66 & IBCB87 & & \\
\hline Control & $1.06 \pm 0.07 \mathrm{a}$ & $1.15 \pm 0.06 \mathrm{a}$ & $1.08 \pm 0.05 \mathrm{a}$ & $1.16 \pm 0.06 \mathrm{a}$ & $1.71 \pm 0.12 \mathrm{a}$ & $1.16 \pm 0.07 a$ \\
\hline Azadirachtin & $0.81 \pm 0.07 b c$ & $0.76 \pm 0.06 b$ & $0.82 \pm 0.04 b c$ & $0.77 \pm 0.04 b$ & $0.82 \pm 0.06 b c$ & $0.89 \pm 0.03 b c$ \\
\hline Thiamethoxam & $1.03 \pm 0.06 \mathrm{ab}$ & $1.00 \pm 0.04 a$ & $1.03 \pm 0.05 \mathrm{ab}$ & $0.98 \pm 0.04 a$ & $1.12 \pm 0.06 \mathrm{ab}$ & $1.00 \pm 0.06 \mathrm{ab}$ \\
\hline Deltamethrin & $0.55 \pm 0.04 \mathrm{~d}$ & $0.67 \pm 0.04 b$ & $0.66 \pm 0.06 \mathrm{~cd}$ & $0.69 \pm 0.05 b$ & $0.35 \pm 0.05 b c$ & $0.78 \pm 0.05 c$ \\
\hline Acephate & $0.64 \pm 0.04 \mathrm{~cd}$ & $0.66 \pm 0.05 b$ & $0.55 \pm 0.07 \mathrm{de}$ & $0.62 \pm 0.04 b$ & $0.45 \pm 0.09 b c$ & $0.69 \pm 0.04 c$ \\
\hline Methomyl & $0.22 \pm 0.05 \mathrm{e}$ & $0.29 \pm 0.04 c$ & $0.40 \pm 0.06 \mathrm{e}$ & $0.25 \pm 0.04 c$ & $0.16 \pm 0.03 c$ & $0.19 \pm 0.03 \mathrm{~d}$ \\
\hline$F$ & 33.28 & 36.14 & 22.21 & 48.47 & 6.93 & 48.59 \\
\hline df & 5,54 & 5,54 & 5,54 & 5,54 & 5,54 & 5,54 \\
\hline$P$ & $<0.01$ & $<0.01$ & $<0.01$ & $<0.01$ & $<0.01$ & $<0.01$ \\
\hline
\end{tabular}

Means in each column followed by same letter do not differ significantly by the Tukey's test $(P<0.05)$.

Table 6. Viability of conidia (\%; $\pm \mathrm{SE}$ ) of the most virulent entomopathogenic fungi isolates to $P$. $x$ ylostella when in contact with insecticides registered for the control of cabbage crop pests

\begin{tabular}{|c|c|c|c|c|c|c|}
\hline \multirow[t]{2}{*}{ Treatments } & \multicolumn{4}{|c|}{ B. bassiana } & \multirow{2}{*}{$\begin{array}{l}\text { I. sinclairii } \\
\text { ARSEF7973 }\end{array}$} & \multirow{2}{*}{$\begin{array}{c}\text { M. rileyi } \\
\text { LCMAP101 }\end{array}$} \\
\hline & IBCB01 & IBCB18 & IBCB66 & IBCB87 & & \\
\hline Control & $93.80 \pm 1.24 \mathrm{a}$ & $94.80 \pm 1.07 a$ & $90.60 \pm 0.93 a$ & $93.00 \pm 1.38 \mathrm{a}$ & $92.80 \pm 1.16 a$ & $91.80 \pm 0.66 a$ \\
\hline Azadirachtin & $84.80 \pm 1.93 a$ & $83.20 \pm 2.22 \mathrm{a}$ & $75.20 \pm 2.78 a$ & $88.80 \pm 2.01 \mathrm{a}$ & $79.00 \pm 1.58 \mathrm{a}$ & $83.40 \pm 2.01 \mathrm{a}$ \\
\hline Thiamethoxam & $90.80 \pm 1.66 a$ & $90.80 \pm 1.16 \mathrm{a}$ & $87.40 \pm 1.44 a$ & $87.80 \pm 1.24 \mathrm{a}$ & $88.20 \pm 0.86 a$ & $89.00 \pm 1.22 \mathrm{a}$ \\
\hline Deltamethrin & $59.60 \pm 3.11 b$ & $54.20 \pm 4.89 b$ & $47.20 \pm 3.06 b$ & $56.40 \pm 5.28 b$ & $51.80 \pm 6.62 b$ & $43.40 \pm 3.04 b$ \\
\hline Acephate & $34.40 \pm 5.21 c$ & $41.40 \pm 4.72 b c$ & $50.60 \pm 6.92 c$ & $38.20 \pm 5.31 c$ & $34.60 \pm 6.56 \mathrm{bc}$ & $29.20 \pm 2.71 c$ \\
\hline Methomyl & $32.60 \pm 5.19 c$ & $27.00 \pm 3.85 c$ & $26.00 \pm 4.92 c$ & $22.00 \pm 2.72 \mathrm{~d}$ & $17.40 \pm 3.92 c$ & $26.60 \pm 4.68 c$ \\
\hline$F$ & 67.28 & 70.19 & 42.73 & 76.23 & 53.43 & 127.87 \\
\hline $\mathrm{df}$ & 5.24 & 5.24 & 5.24 & 5.24 & 5.24 & 5.24 \\
\hline$P$ & $<0.01$ & $<0.01$ & $<0.01$ & $<0.01$ & $<0.01$ & $<0.01$ \\
\hline
\end{tabular}

Means in each column followed by same letter do not differ significantly by the Tukey's test $(P<0.05)$.

Table 7. Compatibility score between the most virulent entomopathogenic fungi isolates to $P$. xylostella and pesticides registered for the control of cabbage crop pests

\begin{tabular}{|c|c|c|c|c|c|c|c|c|c|c|c|c|}
\hline \multirow[t]{3}{*}{ Treatments } & \multicolumn{8}{|c|}{ B. bassiana } & \multirow{2}{*}{\multicolumn{2}{|c|}{$\begin{array}{l}\text { I. sinclairii } \\
\text { ARSEF7973 }\end{array}$}} & \multirow{2}{*}{\multicolumn{2}{|c|}{$\frac{\text { M. rileyi }}{\text { LCMAP101 }}$}} \\
\hline & \multicolumn{2}{|c|}{ IBCB01 } & \multicolumn{2}{|c|}{ IBCB18 } & \multicolumn{2}{|c|}{ IBCB66 } & \multicolumn{2}{|c|}{ IBCB87 } & & & & \\
\hline & BI & $\mathrm{CC}$ & BI & $\mathrm{CC}$ & BI & $\mathrm{CC}$ & BI & $\mathrm{CC}$ & BI & $\mathrm{CC}$ & BI & $\mathrm{CC}$ \\
\hline Azadirachtin & 84,35 & $\mathrm{C}$ & 74,72 & $\mathrm{C}$ & 82,86 & $\mathrm{C}$ & 70,96 & $\mathrm{C}$ & 73,85 & $\mathrm{C}$ & 84,54 & $\mathrm{C}$ \\
\hline Thiamethoxam & 93,71 & $\mathrm{C}$ & 87,62 & $\mathrm{C}$ & 91,67 & $\mathrm{C}$ & 87,99 & $\mathrm{C}$ & 66,34 & $\mathrm{C}$ & 91,37 & $\mathrm{C}$ \\
\hline Deltamethrin & 59,41 & MT & 61,62 & MT & 64,70 & MT & 51,15 & MT & 37,18 & $\mathrm{~T}$ & 78,91 & $\mathrm{C}$ \\
\hline Acephate & 54,38 & MT & 51,10 & MT & 52,41 & MT & 49,89 & MT & 33,08 & $\mathrm{~T}$ & 55,77 & MT \\
\hline Methomyl & 28,51 & $\mathrm{~T}$ & 28,77 & $\mathrm{~T}$ & 42,92 & MT & 25,46 & $\mathrm{~T}$ & 21,31 & $\mathrm{~T}$ & 28,65 & $\mathrm{~T}$ \\
\hline
\end{tabular}

BI—Biological index, CC—Compatibility classification (as characterized by Alves et al. 2007).

C-Compatible; MT-Moderately Toxic; T-Toxic

used in combination with these fungi in integrated programs for diamondback moth management (Alves et al. 2008).

Thus, the correct use of virulent fungal entomopathogens for use as biological control agents to reduce populations of $P$. xylostella in combination with compatible chemical control products will enable a significant increase in the adoption of integrated management of this pest, couple with a possible reduction in pesticide use with the correlated benefits of reduced ecological impacts from the indiscriminate use of pesticides. The end result of such advances should be the improved state of the cabbage agroecosystem conditions together with positive impacts for both humans and the overall environment.

\section{References Cited}

Abbott, W. S. 1925. A method of computing the effectiveness of an insecticide. J. Econ. Entomol. 18: 265-267.

Almeida, J.E.M., A. Batista Filho, C. Lamas, L. G. Leite, M. Trama, and A. H. Sano. 2003. Avaliação da compatibilidade de defensivos agrícolas na conservação de microrganismos entomopatogênicos no manejo de pragas do cafeeiro. Arq. Inst. Biol. 70: 79-84.

Alves, S. B. 1998. Controle microbiano de insetos. FEALQ, Piracicaba, SP.

Alves, S. B., M. L. Haddad, M. Faion, G. C. Baptista, and L. S. Rossi-Zalaf. 2007. Novo índice biológico para a classificação de agrotóxicos para fungos entomopatogênicos. In Resumos, 10th Simpósio de Controle Biológico. Brasília, Brasil. 
Alves, S. B., R. B. Lopes, S. A. Vieira, and M. A. Tamai. 2008. Fungos entomopatogênicos usados no controle de pragas na América Latina, pp. 69110. In S. B. Alves and R. B. Lopes (eds.), Controle microbiano de pragas na América Latina. FEALQ, Piracicaba, Brasil.

Anaisie, P., V. Eziah, and E. Owusu. 2011. The potential of indigenous entomopathogenic fungi for the management of the diamondback moth, Plutella xylostella L. (Lepidoptera: Yponeumeutidae) in Ghana. J. Biochem. Bioinform. 1: 275-281.

Andaló, V., A. Moino, Jr., L.V.C. Santa-Cecília, and G. C. Souza. 2004. Compatibilidade de Beauveria bassiana com agrotóxicos visando o controle da cochonilha-da-raiz-do-cafeeiro Dysmicoccus texensis Tinley (Hemiptera: Pseudococcidae). Neotrop. Entomol. 33: 463-467.

Archana, M. R., and K. Ramaswamy. 2012. Interactive effect of entomopathogenic fungi Paecilomyces fumosoroseus with few organophosphate and pyrethroid pesticides: An in vitro study. Ind. J. Fund. Appl. Life Sci. 2: 10-17.

Attique, M. N. R., A. Khaliq, and A. H. Sayyed. 2006. Cold resistance to insecticides in Plutella xylostella (Lep., Plutellidae) be overcome by insecticide mixtures? J. Appl. Entomol. 130: 122-127.

Barros, R., I. B. Albert, Jr., A. J. Oliveira, A. C. F. Souza, and V. Loges. 1993. Controle químico da traça-das-crucíferas, Plutella xylostella L. (Lepidoptera; Plutellidae) em repolho. Anais da Sociedade Entomológica do Brasil 22: 463-469.

Batista Filho, A., J. E. M. Almeida, and C. Lamas. 2001. Effect of thiamethoxam on entomophatogenic microorganisms. Neotrop. Entomol. 30: 437-447.

Batista Filho, A., Z. A. Ramiro, J. E. M. Almeida, L. G. Leite, E. R. R. Cintra, and C. Lamas. 2003. Manejo integrado de pragas em soja: Impacto de inseticidas sobre inimigos naturais. Arq. Inst. Biol. 70: 61-67.

Batta, Y., M. Rahman, K. Powis, G. Baker, and O. Schmidt. 2010. Investigations into the development in the diamondback moth (Plutella xylostella L., Yponomeutidae: Lepidoptera) to the entomopathogenic fungus Beauveria bassiana (Bal.) Vuiilemin (Deuteromycotina: Hyphomycetes) and the toxin Dipe ${ }^{\circledR}$ of Bacillus thuringiensis. Trends Entomol. 6: 15-21.

Boiça Júnior, A. L., J. C. Janini, B. H. S. Souza, and N. E. L. Rodrigues. 2013. Efeito de cultivares de repolho e doses de extrato aquoso de nim na alimentação e biologia de Plutella xylostella (Linnaeus) (Lepidoptera: Plutellidae). Biosci. J. 29: 22-31.

Botelho, A. A. A., and A. C. Monteiro. 2011. Sensibilidade de fungos entomopatogênicos a agroquímicos usados no manejo da cana-de-açúcar. Bragantia 70: 361-369.

Cardoso, M. O. 1999. Avaliação de repolhos de verão na várzea do estado do Amazonas. Hortic. Bras. 17: 51-53.

Cardoso, M. O., R. F. Berni, C. Krug, and I. C. Antonio. 2012. Danos por Plutella xylostella em couve-de-folhas jovem, afetados pela altura e pelo nitrogênio. Embrapa Amazônia Ocidental, Manaus, Brasil.

Castelo Branco, M., and A. L. Guimarães. 1990. Controle das traças das crucíferas em repolho. Hortic. Bras. 10: 24-25.

Castelo Branco, M., and M. A. Medeiros. 2001. Impacto de inseticidas sobre parasitoides da traça-das-crucíferas em repolho, no Distrito Federal. Pesq. Agrop. Bras. 36: 7-13.

Castelo Branco, M., F. H. França, and G. L. Villas Boas. 1997. Traça-dascrucíferas (Plutella xylostella). Embrapa Hortaliças, Brasília, Brasil.

Castelo Branco, M., F. H. França, L. A. Pontes, and P. S. T. Amaral. 2003. Avaliação da suscetibilidade a inseticidas em populações da traça-dascrucíferas de algumas áreas do Brasil. Hortic. Bras. 21: 549-552.

Chapman, J. W., D. R. Reynolds, A. D. Smith, J. R. Riley, D. E. Pedgley, and I. P. Woiwod. 2002. High altitude migration of the diamondback moth Plutella xylostella to the UK: A study using radar, aerial netting, and ground trapping. Ecol. Entomol. 27: 641-650.

Cintra, E. R. R., E. S. Loureiro, J. E. M. Almeida, M. H. Gassen, A. Batista Filho, I. M. Wenzel, and H. Hojo. 2013. Patogenicidade de Metarhizium anisopliae à cigarra do café Fidicinoides pronoe (Hemiptera: Cicadidae) e sua compatibilidade com agrotóxicos utilizados na cultura do cafeeiro. Biológico 75: 63-70.

Coulson, S. J., I. D. Hodkinson, N. R. Webb, K. Mikkola, J. A. Harrison, and D. E. Pedgley. 2002. Aerial colonization of high Arctic islands by invertebrates: The diamondback moth Plutella xylostella (Lepidoptera:
Yponomeutidae) as a potential indicator species. Divers. Distrib 8: 327334.

Cuthbertson, A. G. S., K. F. A. Walters, and C. Deppe. 2005. Compatibility of the entomopathogenic fungus Lecanicillium muscarium and insecticides for eradication of sweetpotato whitefly, Bemisia tabaci. Mycopathologia 160: 35-41.

Cuthbertson, A. G. S., L. F. Blackburn, P. Northing, W. Luo, R. J. C. Cannon, and K. F. A. Walters. 2008. Further compatibility tests of the entomopathogenic fungus Lecaniciilium muscarium with conventional insecticide products for control of sweetpotato whitefly, Bemisia tabaci on poinsettia plants. Insect Sci. 15: 355-360.

De Bortoli, S. A., A. M. Vacari, R. M. Goulart, R. F. Santos, H. X. L. Volpe, and A. S. Ferraudo. 2011. Capacidade reprodutiva e preferência da traçadas-crucíferas para diferentes brassicáceas. Hortic. Bras. 29: 187-192.

Endersby, N. M., P. M. Ridland, and A. A. Hoffmann. 2008. The effects of local selection versus dispersal on insecticide resistance patterns: Longitudinal evidence from diamondback moth (Plutella xylostella (Lepidoptera: Plutellidae)) in Australia evolving resistance to pyrethroids. Bull. Entomol. Res. 98: 145-157.

Ferronatto, E. M. O. 1984. Abundância de larvas e pupas de Plutella xylostella (Linnaeus, 1758) (Lepidoptera: Plutellidae) em Brassica oleraceae L. var. acephala D. C., mortalidade causada por parasitoides e biologia de Tetrastichus sokolowskii Kurdjmov, 1912 (Hymenoptera: Eulophidae). M.S. thesis, Universidade Federal do Rio Grande do Sul, Porto Alegre.

Filgueira, F. A. R. 2007. Novo manual de olericultura: Agrotecnologia moderna na produção e comercialização de hortaliças. UFV, Viçosa, Brasil.

Gassen, M. H., A. Batista Filho, L. O. Zappelini, and I. M. Wenzel. 2008. Efeito de agrotóxicos utilizados na cultura da goiaba sobre o fungo entomopatogênico Beauveria bassiana (Bals.) Vuill. Arq. Inst. Biol. 75: 327-342.

Godonou, I., B. James, C. Atcha-Ahowe, S. Vodouhe, C. Kooyaman, A. Ahanchede, and S. Korie. 2009. Potential of Beauveria bassiana and Metarhizium anisopliae isolates from Benin to control Plutella xylostella L. (Lepidoptera: Plutellidae). Crop Prot. 28: 220-224.

Gopalakrishnan, C. 1989. Susceptibility of cabbage diamondback moth Plutella xylostella L. to the entomofungal pathogen Verticillium lecanii (Zimmerm) Viegas. Curr. Sci. 58: 1256-1257.

Grzywacz, D., A. Rossbach, A. Rauf, D. Russell, R. Srinivasan, and A. M. Shelton. 2010. Current control methods for diamondback moth and prospects for improved management with lepidopteran-resistant $\mathrm{Bt}$ vegetables brassicas in Asia and Africa. Crop Prot. 29: 68-79.

Hajek, A. E., and R. J. St. Leger. 1994. Interactions between fungal pathogens and insect hosts. Annu. Rev. Entomol. 39: 293-322.

Hernández, M. M., E. Martínez-Villar, C. Peace, I. Pérez-Moreno, and V. Marco. 2012. Compatibility of the entomopathogenic fungus Beawveria bassiana with flufenoxuron and azadirachtin against Tetranychus urticae. Exp. Appl. Acarol. 58: 395-405.

Honda, K. I., Y. Miyahara, and K. Kegasawa. 1992. Seasonal abundance and the possibility of spring immigration of the diamondback moth, Plutella xylostella (Linnaeus) (Lepidoptera: Yponomeutidae), in Morioka City, northern Japan. Appl. Entomol. Zool. 27: 517-525.

Huang, Z. S. Ali, S.-X. Ren, and J.-H. Wu. 2010. Effect of Isaria fumosorosea on mortality and fecundity of Bemisia tabaci and Plutella xylostella. Insect Sci. 17: 140-148.

Jun, M. A. 2000. Laboratory susceptibility of Plutella xylostella to Metarhizium anisopliae and Nomuraea rileyi. Entomologia Sinica 7: 53-57.

Khalil, S. K., M. A. Shah, and M. Naeem. 1985. Laboratory studies on the compatibility of the entomopathogenic fungus Verticillium lecanii with certain pesticides. Agric. Ecosyst. Environ. 13: 329-334.

Maketon, M., P. Orosz-Coghlan, and J. Jaengarun. 2008. Field evaluation of Isaria fumosorosea in controlling the diamondback moth (Plutella xylostella) in Chinese kale. Phytoparasitica 36: 260-263.

Mapa. 2013. Agrofit: Sistema de agrotóxicos fitossanitários. (http://agrofit. agricultura.gov.br/agrofit_cons/principal_agrofit_cons)

Marchioro, C. A., and L. A. Foerster. 2014. Preference-performance linkage in the diamondback moth, Plutella xylostella, and implications for its management. J. Insect Sci. 14: 1-14.

Marques, R. P., A. C. Monteiro, and G. T. Pereira. 2004. Crescimento, esporulação e viabilidade de fungos entomopatogênicos em meios contendo 
diferentes concentrações de óleo de Nim (Azadirachta indica). Ciênc. Rural 34: $1675-1680$

Melo, P. E., M. Castelo Branco, and N. R. Madeira. 1994. Avaliação de gentipos de repolho para a resistência a traça das crucíferas. Hortic. Bras. 12: 19-24.

Méndez, A. 2012. Potencialidad de aislamientos autóctonos de Nomuraea rileyi (Farlow) Samson para el control de Spodoptera frugiperda (J. E. Smith) y Plutella xylostella (L.). Rev. Prot. Vegetal 27: 67-67.

Minitab. 2007. Meet Minitab, version 15th ed. Minitab Inc., State College PA.

Monnerat, R. G., S. C. M. Leal-Bertioli, D. J. Bertioli, T. M. Butt, and D. Bordat. 2004. Caracterização de populações geograficamente distintas da traça-das-crucíferas por susceptibilidade ao Bacillus thuringiensis Berliner e RAPD-PCR. Hortic. Bras. 22: 607-609.

Niassy, S., N. K. Maniania, S. Subramanian, M. L. Gitonga, R. Maranga, A. B. Obonyo, and E. S. Ekesi. 2012. Compatibility of Metarhizium anisopliae isolate ICIPE 69 with agrochemicals used in French bean production. Int. J. Pest Manage. 58: 131-137.

Ohsawa, K. 2001. Efficacy of plant extracts for reducing larval populations of the diamondback moth, Plutella xylostella L. (Lepidoptera: Yponomeutidae) and cabbage webworm, Crocidolomia binotalis Zeller (Lepidoptera: Pyralidae), and evaluation of cabbage damage. Appl. Entomol. Zool. 36: 143-149.

Oliveira, A. C., H. A. A. Siqueira, J. V. Oliveira, J. E. Silva, and M. Michereff Filho. 2011. Resistance of Brazilian diamondback moth populations to insecticides. Sci. Agric. 68: 154-159.

Oliveira, C. N., P. M. O. J. Neves, and L. S. Kawazoe. 2003. Compatibility between the entomopathogenic fungus Beauveria bassiana and insecticides used in coffee plantations. Sci. Agricola 60: 663-667.

Ooi, P. A. C., and W. Kalderman. 1979. The biology of three common pests of cabbages in Cameron Highlands, Malaysia. Malays. Agric. J. 52: 85-101.

Ribeiro, L. P., E. Blume, P. C. Bogorni, S. T. B. Dequech, S. C. Brand, and E. Junges. 2014. Compatibility of Beauveria bassiana commercial isolate with botanical insecticides utilized in organic crops in southern Brazil. Biol. Agric. Hortic. 28: 223-240.

Rocha, R. B., E. A. S. F. Melo, O. O. Santos, and M. A. L. Bittencourt. 2012. Compatibilidade e efeito de produtos comerciais à base de nim e Beanveria bassiana (Bals.) Vuill. sobre Metamasius hemipterus L. (Coleoptera: Curculionidae). Magistra. 24: 39-51.

Santos, A., E. Grijalba, M. V. Zuluaga, M. Gómez, and L. Villamizar. 2013. Compatibilidad in vitro de um bioplaguicida a base de Lecanicillium lecanii (Hypocreales: Clavicipitaceae) com agroquímicos empleados em los cultivos de algodón y berenjena. Rev. Colomb. Biotechnol. 15: 132-142.

Sarfraz, M., and B. A. Keddie. 2005. Conserving the efficacy of insecticides against Plutella xylostella (Lepidoptera: Plutellidae). J. Appl. Entomol. 129: 149-157.

Sarfraz, M., L. M. Dosdall, and B. A. Keddie. 2006. Diamondback moth-host plant interactions: Implications for pest management. Crop Prot. 25: $625-639$.
SAS Institute. 2002. Useŕs guide: statistics, version 9.1. SAS Institute Inc. Cary, NC.

Sayyed, A. H., M. N. R. Attique, and A. Khaliq. 2005. Stability of field selected resistance to insecticides in Plutella xylostella (Lepidoptera: Plutellidae) from Pakistan. J. Appl. Entomol. 129: 542-547.

Schumacher, V., and H.-M. Poehling. 2012. In vitro effect of pesticides on the germination, vegetative growth, and conidial production of two strains of Metarhizium anisopliae. Fungal Biol. 116: 121-132.

Shelton, A. M., J. T. Anoaloro, and J. Barnaro. 1982. Effects of cabbage looper, imported cabbage worm and diamondback moth or fresh market and processing cabbage. J. Econ. Entomol. 75: 742-745.

Silva, I. D. S., G. H. S. Nunes, E. A. L. A. Lima, N. D. Alves, and F. M. C. Feijó. 2006. Avaliação do fungo Beauveria bassiana, associado a mosquicida com método de controle biológico de dípteros de interesse médico veterinário sob condições de laboratório. Agropecuária Científica no SemiÁrido 2: 24-28.

Silva, R. A., E. D. Quintela, G. M. Mascarin, J. A. F. Barrigossi, and L. M. Lião. 2013. Compatibility of conventional agrochemicals used in rice crops with the entomopathogenic fungus Metarhizium anisopliae. Sci. Agricola 70: $152-160$.

Silva, V. C. A., R. Barros, E. J. Marques, and J. B. Torres. 2003. Suscetibilidade de Plutella xylostella (L.) (Lepidoptera: Plutellidae) aos fungos Beauveria bassiana (Bals.) Vuill. e Metarhizium anisopliae (Metsch.) Sorok. Neotrop. Entomol. 32: 653-658.

Suwannakut, S., D. G. Boucias, and C. Wiwat. 2005. Genotypic analyses of Nomuraea rileyi collected from various noctuid hosts. J. Invert. Pathol. 90: 169-176.

Thuler, R. T., S. A. De Bortoli, and J. C. Barbosa. 2007. Eficácia de inseticidas químicos e produtos vegetais visando ao controle de Plutella xylostella. Científica 35: 166-174.

Tian, L., and M.-G. Feng. 2006. Evaluation of the time-concentrationmortality responses of Plutella xylostella larvae to the interaction of Beauveria bassiana with a nereistoxin analogue insecticide. Pest Manage. Sci. 62: 69-76.

Ulmer, B., C. Gillot, D. Woods, and M. Erlandson. 2002. Diamondback moth, Plutella xylostella (L.), feeding and oviposition preferences on glossy and waxy Brassica rapa (L.) lines. Crop Prot. 21: 327-331.

Wenzel, I. M., A. Batista Filho, M. H. Gassen, and A. M. B. Almeida. 2008. Compatibilidade de Lecanicillium lecanii (Hyphomycetes), em condições de laboratório e estufa, aos agrotóxicos utilizados na cultura do crisântemo. Arq. Inst. Biol. 75: 157-166.

$\mathrm{Xu}, \mathrm{D}$., S. Ali, and Z. Huang. 2011. Insecticidal activity influence of 20Hydroxyecdysone on the pathogenicity of Isaria fumosorosea against Plutella xylostella. Biol. Control 56: 239-244.

Zhao, J. Z., H. L. Collins, Y. X. Li, R. F. L. Mau, G. D. Thompson, M. Hertlein, J. T. Andaloro, R. Boykin, and A. M. Shelton. 2006. Monitoring diamondback moth (Lepidoptera: Plutellidae) resistance to spinosad, indoxacarb, and emamectin benzoate. J. Econ. Entomol. 99: 176-181. 